\title{
RIDING ON THE "CRESCENDO” OF POLITICAL PERSONAS: ENGENDERING A FEMALE POLITICAL ICON
}

\author{
Lovie Edwin Seru \& Joel Mokuedi Magogwe
}

\section{ABSTRACT}

This study was based on the observation that the construction and presentation of the self is a prominent feature of the life of every politician. That construction of the self is even more pronounced in male politicians, who clandestinely perceive politics as a male preserve. Because of the prevailing social order's agitation for the sharing of power between men and women, men resort to concealing their true and embodied beliefs about gender equality and women's empowerment by feigning support when speaking in public political spaces. Using the idea of persona, a concept that explains the presentation of the self and "masks" that people wear to construct themselves, this study explored the male dominated political system of Botswana to identify the "deceitful" and "inauthentic" acts of male politicians. The study also used persona to explore gendered political space in Botswana to identify the "true selves" hidden behind male politicians' public selves as they engaged in political activities. The personas in this study have been uncovered through Margaret Nasha's involvement in politics as an important agent and "driver" of the agenda for gender equality and women's empowerment. The choice to use Margaret Nasha's political life story as a conduit to identity and explain political persona "masks" that male politicians wore was informed by the multifaceted roles she played to survive political muddles. Using document analysis and semi-structured interviewing methods, this study has unearthed that Margaret Nasha's involvement in politics exposed her male political colleagues' hidden selves and the influence of patriarchy in continued gender inequality in Botswana politics.

\section{KEY WORDS}

Persona; Identity; Politics; Democracy; Empowerment; Self

\section{INTRODUCTION}

Margaret Nasha has become a household name in Botswana's political arena. Despite Nasha herself being very sceptical about it, her name would appear on anyone's list of the most successful and decorated female politicians in Botswana. Her political success may be attributed to the nuanced and multifaceted roles that she assumed in "driving" the agenda for gender equality and women's empowerment. Those multifaceted roles were instrumental in enabling her to overcome male chauvinism and cultural hurdles, and consequently thrive in a rough, overdemanding, and male-dominated political system.

As will be demonstrated below, the roles she played were also instrumental in unearthing the personas male politicians adopted to conceal their true and embodied beliefs. In 
other words, through her political activism and efforts as a driver of women's empowerment and gender equality, she exposed inconsistencies between the public political positions of her male political colleagues in the Botswana Democratic Party (BDP) and their covert activities and private beliefs. This included pretending to support an agenda for women's empowerment and gender equality and adhering to all democratic ideals. Thus, the conflict between male BDP members' public positions and their private beliefs, activities and perceptions about gender equality, democracy and women's empowerment, resonates with the idea of persona as described by scholars such as Glenn D'Cruz, P. David Marshall, Erving Goffman, Anthony Elliott and others cited in this work.

While Margaret Nasha's roles as "driver" of the agenda for gender equality and women's empowerment, principled democrat, strong-willed and unapologetic female politician, and reluctant factionalist catapulted her political career, it simultaneously and ironically exposed her to ridicule, subversion, and contestation by the men who publicly claimed to believe in what she was fighting for. Consequently, her assumed roles uncovered a dichotomy between the men's public political proclamations and their specific courses of action within the BDP. Thus, it is the contention of the authors of this paper that the negative reactions of the male politicians towards her gender equality activism and ambition reveals the wearing of "masks" on their part. Persona "masks" are what P. David Marshall would call inauthenticity of the characters or personages that the audiences are covertly invited to believe. The objective of this paper, therefore, is to identify how Nasha's everyday political engagements within a male-dominated political space unearthed the true beliefs and perceptions held by the men about gender equality, democracy, and women's empowerment which had previously remained hidden behind the "masks" that they wore.

It should be noted that the emphasis of this study was not on Margaret Nasha's political life story per se. Rather, her political life story was used to identify and explain the personas evident in the male-dominated Botswana political system. It is also important to note that the roles that Nasha assumed enabled her to become a diplomat, member of Parliament (MP), Assistant Minister, Minister, and finally Speaker of the Botswana Parliament. Undoubtedly, these positions represent achievements that everyone who believes in women playing active roles in politics and taking up positions of power would not fail to celebrate. To this end, Nasha's political journey as addressed in this paper, and which inadvertently exposed personas in her political movement, begins with her role as a diplomat and ends with her fights with the leadership of the ruling Botswana Democratic Party (BDP).

\section{PERSONA}

The word persona refers to the social role, self-conceived character, or a person's character as professed and seen by other people (D'Cruz). Glenn D'Cruz further posits that a persona is a "mask" people wear to conceal their original characters to create an impression upon others. Marshall concurs with D'Cruz when he posits that persona is the character people espouse, exhibit, or take up. Marshall and D'Cruz also point out that persona could be based on deceptive or fictitious displays of character.

People who wear persona "masks" or assume deceptive roles surreptitiously invite their audiences to believe that those roles are authentic (Goffman). In other words, they covertly expect their audiences to believe that the characters they see actually have the personal traits that they espouse (Goffman). Marshall confirms that, notwithstanding the inauthenticity of the characters or personages that the audiences are surreptitiously invited to believe, the "masks" are often consistent with the real public culture. Thus, even though it may seem that the performance displays the character of the performer, the performance often serves solely to 
portray a character relevant to the task being performed, not the true character of the performer (Goffman).

Persona can also be viewed as a deliberate subjugation of real identities for the purpose of identifying with prevailing social order. This kind of suppression of authentic identities is easy to achieve since some identities are socially constructed (Seru). Seru's observation that the subjugation of identities is achievable resonates with Anthony Elliott's idea that some identities are established through personal activities and choices, and the modelling of thoughts, dispositions, feelings, desires, and subjective experiences in sync with the social context and prevailing social activities. To illustrate this point, Elliott observes that:

The way in which an individual acts in the presence of family members or loved ones is likely to be rather different from encounters with, say, work colleagues or sporting partners. From family, school and work to shopping, community associations or surfing the Internet: all these social fields summon forth, and through them we construct different sorts of selves. (53)

Elliott further argues that people act out or perform particular roles in relationships with others, and that we have an awareness of identities we want to adopt as we move from one social setting to another, something Goffman calls "fronting" (13). Like Elliott, Goffman also argues that the synchronisation of personal life with public life constitutes the core of persona.

Marshall argues that persona involves the fabrication of roles to achieve particular purposes. Goffman raises the same point when he suggests that the individual performances or shows that people put on are done for the benefit of others. This implies that if politicians adopt inauthentic personas this should not be viewed negatively. Rather, it should be seen in its positive context; as Goffman states, fabrication of roles can be triggered by desirable purposes of changing and bettering people's lives. Goffman further asserts that individuals may deceive other people for what they consider to be their own good and the good of those people.

The discussion above demonstrates that, in a broader sense, persona represents enunciation of a range of actions, identities, and socio-cultural practices through which false identity positions could be developed. Kevin Hetherington argues that the development of new inauthentic identity positions is linked to theatricality in that those identity positions are established and enacted through performances. It should be noted that Hetherington uses the term "theatricality" to mean the social construction of self through performances and creation of personas. During the playing out of such theatricality, real selves remain outside such performances and become unobservable and distant to audiences who will believe that the characters they see truly have the attributes being displayed (Hetherington). Just as Goffman suggests presentation of the self is "impression management" (49), Hetherington considers presentation of the self to be closely associated with impression management, co-ordination of behaviour, and role assumption. In this way, this theatricality is enacted.

In conducting this study, the authors of this paper were therefore interested in the particular roles Margaret Nasha played to determine the roles other women elsewhere can play for success in politics. This research was also meant to expose political chicaneries and contradictions in men's perceptions about gender equality and women's empowerment, especially in African politics. Cultural differences, including values and practices, influence the construction and presentation of identities. Elliott notes that culturally constructed identities are incessantly bombarded with shifting cultural stimuli and fragmentation of social attributes. Given this understanding of the role of culture and context in influencing the construction and presentation of self, this study also sought to find out how the Botswana political landscape, and Botswana voters' political orientations and expectations, influenced the construction of 
identities and presentation of selves. As already noted, the main idea was not to study Margaret Nasha's political life. Rather, it was to establish how the roles she played to emancipate women exposed personas in the Botswana political environment, and to determine the lessons that other women can learn from and use for success in politics.

\section{METHODS}

This study used document analysis and semi-structured interview as methods of data collection. With the document analysis method, Margaret Nasha's narrations in her memoir, entitled Madam Speaker, Sir!: Breaking the Glass Ceiling, One Woman'Struggles, provided a singular document for reading and analysis. The document analysis method focused primarily on her political and professional life stories, with the objective to discover the roles that she assumed in order to attain what many might think was an unachievable feat. Most importantly, the objective of this analysis was to show how the roles she played exposed the personas in her political movement. The analysis also sought to establish how the personas adopted by her male colleagues influenced her political career. A semi-structured interviewing method was used mainly to augment the findings of the document analysis method. As a result, the focus of the interview was on her experiences as she spearheaded the agenda for gender equality and women's empowerment.

\section{PUBLICLY EMBRACING WOMEN'S EMPOWERMENT, BUT PRIVATELY NOT SUPPORTING IT}

The "deceitful" acts of the male politicians manifested through their lack of support for Margaret Nasha's activism in the struggle for women's empowerment. According to Nasha, she experienced resistance and contestation from the men who, in public political campaigns, had vehemently professed support for women's empowerment. The BDP's political manifestos emphasised candid support for gender equality and women's empowerment. It was therefore ironic and disingenuous of them to vilify Nasha when she became an important agent driving the women's empowerment agenda in the country. Also, as shown in Nasha's narration in the paragraphs quoted below, despite the men's public proclamations supporting shared power between men and women, and similar statements in the party manifestos, there was a conspicuous absence of involvement from women in decision-making processes in the party. Thus, by professing support for women's empowerment in public political domains and official party documents, and yet at the same time privately resisting sharing power with women, the men were engaged in performative acts which Goffman would call the synchronisation of political beliefs with public expectations. The men were surreptitiously constructing different sorts of selves in public political domains and official documents to deceive voters into thinking that they stood for what they (the voters) stood for.

On the other hand, Nasha's work and focus on the plight of women and her agitation for their empowerment presents her as the epitome of social change and women's empowerment. She states in her memoir that there were many signals that men were not willing to solve women's problems. Nasha warns against complacency in the fight for women's empowerment:

Until and unless women in this country wake up and smell the coffee, political power sharing will remain a mirage. Men are in this business to rule and to be in control. There is no Father Christmas doling out gifts of leadership positions in this business. If we want power, we must work hard to achieve it. (Nasha, Madam Speaker, Sir! 156)

With these words, Nasha identifies the role of patriarchy in the continued gender inequality in Botswana politics. Simply put, in the cautionary note above she presents her male political 
colleagues as an egotistical and self-centred lot who privately did not want to share power with their female counterparts. As revealed in her memoir, Nasha became seriously involved in the struggle for women's empowerment throughout her political career. In fact, her memoir indicates that her resolve to agitate for women's empowerment started when she was in the civil service. For instance, she joined a group called Women Development Planning and Advisory Council (WODPLAC) in the 1970s, long before she entered politics. After joining active politics, her distinguished contribution to women's empowerment came to include being a member of a women's organisation called Emang Basadi (which means means "Women, Stand up" in English (Madam Speaker, Sir! 152)), being the president of the Botswana Caucus for Women in Politics, and fighting fervently to get her female colleagues within the BDP into leadership positions (Nasha, Madam Speaker, Sir!). The main agenda of Emang Basadi was power sharing. Its specific objective was therefore to identify and agitate for a change in the laws that discriminated against women. The Botswana Caucus for Women in Politics aimed to encourage women across the political divide to work hard towards equal political representation (Nasha, Madam Speaker, Sir!).

During the interview, Margaret Nasha indicated that women's empowerment entails having women involved in political decision-making processes for the country at the highest level, as well as the involvement of political parties and other civic organisations the women belonged to at the micro level. According to Nasha, the absence, and lack of involvement, of women in decision-making processes led to situations where women's rights were denied. She lamented how she and the other women in parliament (who have always been the minority) used to witness cases where the men (who have always been the majority) passed policies and laws that favoured them to the detriment of women. She provided an example of a case where, during the drought period, the male parliamentarians wanted the government to subsidise cattle-feed. At the same meeting, the same men vehemently opposed the suggestion by female parliamentarians to have chicken-feed subsidised as well. Their support for the subsidisation of cattle-feed, and refusal to have chicken-feed subsidised as well, was an indication of a selfserving mentality. Male support for the subsidisation of cattle-feed but not chicken-feed reflects the gendered politics in parliament, as many of the men in Botswana (including male parliamentarians) are involved in the cattle industry and the women are involved in chicken farming.

The case of the men who publicly proclaimed gender equality but in parliament passed laws favouring themselves rather than women (because men were in the majority) can be considered an instance of wearing persona masks. Their deceptive actions in public political spaces were self-serving. The male politicians surreptitiously wanted potential voters to believe that they embraced gender equality and the empowerment of women to gain votes from women during elections. In other words, they wore persona masks for purposes of changing or bettering their lives at the expense of the women they pretended to represent. Their actions show that while they "preached" gender equality and women's empowerment to the voting publics, their real selves remained outside such performances. It is through Margaret Nasha's women's empowerment activism that their real selves got exposed.

\section{PRIVATELY ACKNOWLEDGED, BUT PUBLICLY REPUDIATED}

Despite the existence of factional politics in the ruling BDP, the BDP's male-dominated leadership publicly denied such factions. They steadfastly and repeatedly invited the voting public to believe that no factions existed in the party. This kind of demeanour resonates with what scholars such as Marshall and D'Cruz call the wearing of a "mask" to conceal the truth. Nasha's narration of how the leadership of the party untiringly and relentlessly issued public 
statements denying the existence of factions within the party just to protect the image of the party presents a persona-the persona of deceiving through denial of the truth to protect party image. That the party leadership knew well that indeed factionalism existed within the party, but went all out to deny it, resonates with Marshall's position that persona is predicated on "deception," "inauthenticity," and "fiction." As mentioned above, Goffman also argues that people who assume deceptive roles usually clandestinely persuade their audiences to believe that those roles are authentic. It can thus be argued that by making strongly worded public statements denying the existence of factions within the party, the party leadership was attempting to coerce Batswana (people of Botswana) into believing what was actually not the truth.

Contrary to this denial, Nasha asserts that when she joined active politics she found factional politics endemic, not only in the ruling BDP, but in the opposition parties as well. She found it baffling and ludicrous that people belonging to the same party, and supposedly holding the same political views and vision, could fight for party positions along factional lines.

However, she also admits in her memoir, and in a response to an interview question, that she was introduced into the most powerful faction during her early days in politics and attended factional group meetings under the cover of darkness. In her book, she explains the circumstances that made her get involved in factional politics: "You had to either fight them or join them, and if you chose to join them, then you joined whichever faction that seemed to make sense to you at that time" (Nasha, Madam Speaker, Sir! 101).

It is also worth mentioning that Nasha benefitted immensely from factional politics. Owing to her joining the Kwelagobe faction (the faction was named after its leader Mr Daniel Kwelagobe), which at the time was the most powerful, she was elected the chairperson of the Women's Wing of the party when she was new and politically inexperienced. She defeated a veteran politician whose only "sin" was belonging to a weaker faction (Nasha, Madam Speaker, Sir!). Also, along factional lines, she represented the party in the Gaborone Central Constituency and eventually became an elected Member of Parliament in 1999 (Nasha, Madam Speaker, Sir!).

\section{PUBLICLY ALIGNED TO DEMOCRATIC IDEALS, BUT PRIVATELY NOT}

Even though the ruling party leadership publicly claimed to encourage women to take up positions of power within the party and the country, they covertly did not want to see women being elevated to such positions. This was evidenced by their disdain of Margaret Nasha's ambition. Furthermore, the leadership of her constituency became suspicious that she harboured the ambition of becoming vice president of Botswana. The position of vice president would put her at a pole position to become president given the provision of automatic succession to the position of president in the country's constitution. Despite it being her democratic right to compete for any position in the party and the country, her detractors within the BDP did not want to see that happening. They therefore embarked on a spirited campaign to bring her down. The BDP's opposition to having Nasha at the helm of the party and country leadership, when they publicly claimed to adhere to democratic ideals, was not only undemocratic but also akin to wearing a persona "mask."

Furthermore, it is significant to note what transpired at a congress during a review of the Party constitution. According to Nasha, among the recommended changes was one that sought to give the president sole power to expel members of the party who were accused of serious wrongdoing, without following due processes stipulated in the party constitution. As far as Nasha was concerned, allowing the president to have such power would be undemocratic, as that would deny people the right to be heard. She vehemently objected to the endorsement of this change (Nasha, Madam Speaker, Sir!). As a result, she was denigrated by the party 
leadership who publicly claimed to believe in democracy. This too was not only undemocratic but also predicated on falsehood. In other words, announcing that they believed in democracy while doing the opposite at party level was deceptive to the public.

Despite proclamations by the BDP leadership that they were democratic, their demeanours (as seen through the narration of Margaret Nasha) do not confirm that. On the contrary, it is Nasha herself who comes across as a principled democrat who held high ideals about empowering ordinary members of the party, and the whole nation. Also, what set her apart from other senior members of the party is that she believed ordinary members of the party had to take part in decisions affecting the party. She also believed that ordinary members had to exercise freedom of choice regarding who should be elected into structures of the party (Nasha, Madam Speaker, Sir!). This is manifested by her objection at one point to a decision of the constituency committee. The committee aimed to impose the entire structure of the party, including who would and should take positions in the party, on ordinary members. As she states in her memoir: "I honestly did not think that we needed that level of dictatorship in the politics of modern Botswana” (Nasha, Madam Speaker, Sir! 98).

As someone who held high democratic ideals, Nasha managed to endear herself to ordinary members of the party (voters). However, that led to altercations with the constituency and party leadership (Nasha, Madam Speaker, Sir!). Those altercations unveiled a serious dichotomy between what the party leadership wanted the public to believe they cherished and embraced and what they did secretly at the party leadership level. Her adherence to the principles that the party wanted everyone to believe that they cherished uncovered undemocratic tendencies within the BDP. Given that the party manifestos emphasised democracy, and that democracy formed one of the building blocks of the political mission and vision of the BDP (Botswana Democratic Party Election Manifesto 2014-2019), the altercations that ensued following Nasha's show of adherence to democratic ideals revealed that the party leadership did not stand by what they wanted the public to believe they stood for. This tendency resonates with what Hetherington calls the development of inauthentic identity position. Just as Hetherington observes, the position that the BDP wanted to portray to the voting public could be likened to theatricality in that it was established and enacted through performance-such as in the writing in manifestoes and other party documents, as well as verbal narrations by the party leadership in public political campaigns. Having democracy as their key principle and espousing that in public political spaces at all times while not doing so through inner party operations can be said to be an instance of wearing a political persona "mask."

\section{PUBLICLY ALIGNED TO THE AGENDA OF GENDER EQUALITY, BUT PRIVATELY NOT}

Margaret Nasha was aware when she joined active politics that politics would be a struggle, further confiding in the interview that "for a woman the struggle is twice as much." Indeed, during her political activism she had to contend with not only male chauvinism but also with women who, due to their cultural orientations, betrayed women's struggles. It is safe to say that if she had not adopted an unapologetic stance and maintained a strong-willed personality she would have given up on politics. As mentioned above, she had fights with the men who could not understand how a woman could be ambitious enough to even harbour aspirations of becoming vice president. As far as she was concerned, she qualified to be vice president by birth and education. She therefore could not see anything wrong with wishing to be vice president (Nasha, Madam Speaker, Sir!). In any case, she had proven herself by performing exceptionally well as a cabinet minister. She thus openly talked about her "dream" of occupying the second highest office in the land (Nasha, Madam Speaker, Sir!). 
In her memoir, she highlights how the men used the catchphrase "What does this woman really want?", meaning "this woman, it seems, wants everything," just to vilify her (Nasha, Madam Speaker, Sir! 98). She was not perturbed by these chauvinist and hateful remarks. As far as she was concerned, she deserved to have what the men wanted to-and could-have, without anybody questioning their abilities (Nasha, Madam Speaker, Sir!). The extract below captures Nasha's melancholy about the altercations she had with the men over her aspirations for the position of vice president:

Such is the reality of a woman's life in politics, especially in our peculiar situation where women who aspire for positions of leadership and power are detested and viewed with suspicion. Sometimes, it does look like we are fighting a losing battle, but as I always say it, someone has to do this job so that up and coming young women know that it can be done. (Madam Speaker, Sir! 120)

Standing against this strong force of male chauvinism and not being apologetic about it made Nasha an embodiment of resilience and, in contrast, presented the men as an embodiment of male chauvinism. Nasha's words above underscore the harsh reality of the life of women in politics and is also an indictment of the ruling party's double standards. In public, the BDP "preached" gender equality and prided itself on developing a national policy on gender and development (Botswana Democratic Party Election Manifesto 2014-2019). Despite this, they still did not have in place procedures for responding to gender sensitive issues. It thus appears that the development of a policy on gender and development was done to deceptively make the voting public believe that the BDP strived to create an environment where men and women were equal. In other words, the subversion, contestation and ridicule that women who wanted to assume positions of power in the party had to contend with was ironic. This also points to impression management and stage-managed public performances by the BDP and is indeed a replica of what Hetherington would call a social construction of self through performances and creation of personas.

As mentioned previously, Hetherington argues that during such stage-managed performances the real self remains outside and becomes unobservable to people who come to believe that the characters they see truly have the attributes being displayed. In short, even though the BDP's politicians and manifestos publicly professed gender equality, their actual gender insensitivity remained outside such pronouncements. Hetherington's explanation also suggests that the people who listened to BDP's pronouncements about gender equity would not believe that the women in the BDP could be ridiculed by the men for aspiring for positions of leadership which men aspired for and occupied.

\section{CONCLUSION}

This study has established that in politics one can benefit from the personas of others. As shown in this paper, Margaret Nasha capitalised and benefited hugely from the personas of her male political colleagues who incidentally and privately were not aligned to the women's empowerment agenda and democratic ideals. The male politicians behaved like Colonel Qaddafi, who would say one thing but go on to do something diametrically opposed to what he said and wanted people to believe (Totman \& Hardy).

This study has also shown that public expectations and cultural orientations profoundly influence the construction and presentation of selves in political public spheres. Despite privately not aligning with the agenda of gender equality and women's empowerment, male politicians displayed vehement support for this in public political domains. They knew that Botswana voters embraced gender equality and the empowerment of women, hence creating an 
impression that they too stood for those democratic ideals. Their courses of action were stage managed so that they could be in line with voters' expectations and cultural orientations.

As shown above, Margaret Nasha encountered cultural hurdles that included men who did not want to share power with women, and women who betrayed the struggle for women's empowerment because they too did not believe in political power sharing. In order to overcome these, she adopted the roles of a tireless fighter for women's inclusion and advancer of public knowledge. To some people, these roles could also be personas. While it is true that women often wear persona "masks" in order to parry political onslaughts and to negotiate the turbulence of cultural beliefs that are inherent in politics, the same cannot be said about Nasha. She indicates in her memoir that the roles she played were her honest and embodied beliefs. Thus, even though she was able to endear herself to the masses through playing those roles, they cannot be called personas. But, one thing is certain about Nasha's political life story; it represents an "epithet" that women in politics can learn from. Moeng reports that during the launch of Madam Speaker, Sir!: Breaking the Glass Ceiling; one woman's struggle, Justice Key Dingake described Nasha's political story as a good lesson and a reason for women and girls to "walk taller," and for society to double their efforts in ensuring that there are women in politics and other spheres of life. Nasha's fight for women's empowerment and her survival in political muddles presents her as a role model for women across the political divide.

\section{WORKS CITED}

Botswana Democratic Party Election Manifesto 2014-2019. Gaborone: Botswana Democratic Party. Print.

D’Cruz, Glenn. "Darkly Dreaming (in) Authenticity: The Self/Persona Opposition in Dexter." $M / C$ Journal 17.3 (2014): n. pag. Web.

Elliott, Anthony. Concepts of the Self. Cambridge: Polity Press, 2014. Print.

Goffman, Erving. The Presentation of Self in Everyday Life, Edinburgh: University of Edinburgh Social Sciences Research Centre, 1956. Print.

Hetherington, Kevin. Expression of Identity: Space. Performance and Politics. New Delhi: Sage Publications, 1998. Print.

Marshall, P David. "Seriality and Persona." M/C Journal 17.3 (2014): n. pag. Web.

Moeng, Gothataone. "Madam Speaker Sir' Breaks Glass Ceiling." The Mmegi Monitor Online, 2014. Web. Accessed 9 September 2016.

Nasha, Margaret. Madam Speaker, Sir!: Breaking the Glass Ceiling; one woman's struggle. Gaborine: Diamond Educational Publishers, 2014.

---. Personal Interview. 25 August 2016.

Seru, Lovie Edwin. "Social Masks and Dramaturgy in Diabetes Health Campaigns in Low Resourced and "closed" Communities." International Research Journal of Social Sciences 6.1 (2016): 23-36. Print.

Totman, Sally and Mat Hardy. "The Charismatic Persona of Colonel Qaddafi." M/C Journal 17.3 (2014): n. pag. Web. 